\title{
Identification of airborne fungi's concentrations in indoor and outdoor air of municipal wastewater treatment plant
}

\author{
Nastaran Talepour ${ }^{\circledR}$, Mohammad Sadegh Hassanvand $^{2,3}{ }^{\circledR}$, Effat Abbasi-Montazeri $^{4^{\circledR}}$, Seyed Mahmoud Latifi ${ }^{5^{\circledR}}$, \\ Neamat Jaafarzadeh Haghighi Fard ${ }^{6,7^{*} \mathbb{D}}$, Bamshad Shenavar $^{\mathbb{(}(\mathbb{C}}$ \\ ${ }^{1}$ Department of Environmental Health Engineering, Health Faculty, Ahvaz Jundishapur University of Medical Sciences, Ahvaz, Iran \\ ${ }^{2}$ Center for Air Pollution Research (CAPR), Institute for Environmental Research (IER), Tehran University of Medical Sciences, Tehran, \\ Iran \\ ${ }^{3}$ Department of Environmental Health Engineering, School of Public Health, Tehran University of Medical Sciences, Tehran, Iran \\ ${ }^{4}$ Department of Microbiology, School of Medicine \& Infectious and Tropical Diseases Research Center, Ahvaz Jundishapur University \\ of Medical Sciences, Ahvaz, Iran \\ ${ }^{5}$ Diabetes Research Center, Health Research Institute, Ahvaz Jundishapur University of Medical Sciences, Ahvaz, Iran \\ ${ }^{6}$ Environmental Technology Research Center, Ahvaz Jundishapur University of Medical Sciences, Ahvaz, Iran \\ ${ }^{7}$ Department of Environmental Health Engineering, Health Faculty, Ahvaz Jundishapur University of Medical Sciences, Ahvaz, Iran \\ ${ }^{8}$ Department of Environment, Faculty of Agriculture and Natural Resource, Science and Research Branch, Islamic Azad University, \\ Ahvaz, Iran
}

\begin{abstract}
Background: Airborne fungi play an important role the quality of indoor and outdoor air. The aim of this study was to investigate the concentration of airborne fungi around different parts of the wastewater treatment plant (WWTP) in the west of Ahvaz and its relationship with some important meteorological parameters.

Methods: This study was conducted on a WWTP in the west of Ahvaz during 4 months in both cold and warm seasons. Samples were collected from 2- and 10-m intervals of the grit chamber (GCh), primary sludge dewatering basin (PSDB), and aeration tank (AT), as well as $60 \mathrm{~m}$ upstream (US), downstream (DS), and administrative building (AB) of the WWTP. Bioaerosols were collected using passive sampling method. Temperature, humidity, wind speed, wind direction, and ultraviolet index (UV) were also measured at the time of sampling.

Results: The total concentration of fungi was $46.1 \pm 43 \mathrm{CFU} /$ plate/h. The highest concentration of fungi $(92.2 \pm 28.12 \mathrm{CFU} /$ plate/h) was found $2 \mathrm{~m}$ away from the GCh in the cold season and the lowest one $(24.6 \pm 6.67 \mathrm{CFU} / \mathrm{plate} / \mathrm{h})$ was found at the 10 -m distance of the AT in the warm season. The dominant fungal genus included Cladosporium, Alternaria, Yeast, and Aspergillus, respectively. Also, there was a significant relationship between the degree of fungal contamination in different units, the US and DS of the WWTP, and there was a negative relationship between the release of fungi and UV.

Conclusion: According to the results, grit chamber plays an important role in releasing airborne fungi. Also, airborne fungi were reduced with an increase in distance and UV.

Keywords: Bioaerosols, Fungi, Meteorological parameters, Wastewater treatment plant

Citation: Talepour N, Hassanvand MS, Abbasi-Montazeri E, Latifi SM, Jaafarzadeh Haghighi Fard N, Shenavar B. Identification of airborne fungi's concentrations in indoor and outdoor air of municipal wastewater treatment plant. Environmental Health Engineering and Management Journal 2020; 7(3): 143-150. doi: 10.34172/EHEM.2020.17.
\end{abstract}

Article History:

Received: 12 February 2020

Accepted: 9 April 2020

ePublished: 4 August 2020

\section{Introduction}

The effect of airborne microorganisms on the human health is a serious issue and their concentration is related to the spread of human diseases (1). Consequently, controlling the concentration and capability of bioaerosols in the contaminated environments is important especially for protecting people's health (2). Overall, in recent years, extensive studies have indicated the relationship between particle concentrations and mortality, respiratory diseases, cardiovascular diseases, and other disorders (36). Bioaerosols can be solid particles, liquid or volatile compounds (7). The atmospheric aerosols can exist in the non-living particles form (antigenic particles, dead skin cells, dandruff, and patches of insects and plants) or the living particles form (bacteria, fungi, viruses, etc) $(8,9)$. Nowadays, approximately more than 2000 fungal species 
that have not been infectious to human beings are among the opportunistic pathogens, which are progressively increasing (10). The size of the fungi ranges from 1 to $30 \mu \mathrm{m}$ (11). Many microorganisms' resources are human activities including wastewater treatment plants (WWTPs) (12). WWTP can affect the health condition in different ways, depending on the capacity of the WWTP, technology, and treatment methods $(13,14)$. A specific disease called "wastewater workers syndrome" caused by bioaerosols has been identified among WWTP workers. The symptoms of this disease are weakness, fever, acute rhinitis, and gastrointestinal disorders $(15,16)$. One of the most important health problems caused by the exposure to aerosols is respiratory complications and poor performance $(17,18)$. Exposure to airborne fungi increases the risk of various morbidities, such as allergic diseases, asthma, rhinitis, conjunctivitis, eczema, and decreased lung function (19). Niazi et al found that primary treatment had the highest impact on fungal concentration (14). Also, Fathi et al reported that the highest fungal concentration was in the downwind of the aeration basins, and observed a significant correlation between fungal concentrations inside and outside the plant (16). Kermani et al reported high fungal concentrations around the grit chamber basin (20). The potential risk of bioaerosols depends on the meteorological parameters, the type of exposure, and the response to individual immunology (21). The impact of pollutants on the human health can be due to the chemical and biological composition of atmospheric particles, where the role of biological particles is significant. Considering the effects of fungal aerosols on the health of WWTPs workers and those who lives around it, and the role of WWTPs in producing fungal aerosols, the concentration of airborne fungi around grit chamber (GCh), primary sludge dewatering basin (PSDB), and aeration tank (AT) of Ahvaz WWTP and its relationship with some of the important meteorological parameters were investigated in this study. This study can increase public awareness for a better understanding of air quality in the WWTPs in regions with similar treatment systems and climatic conditions.

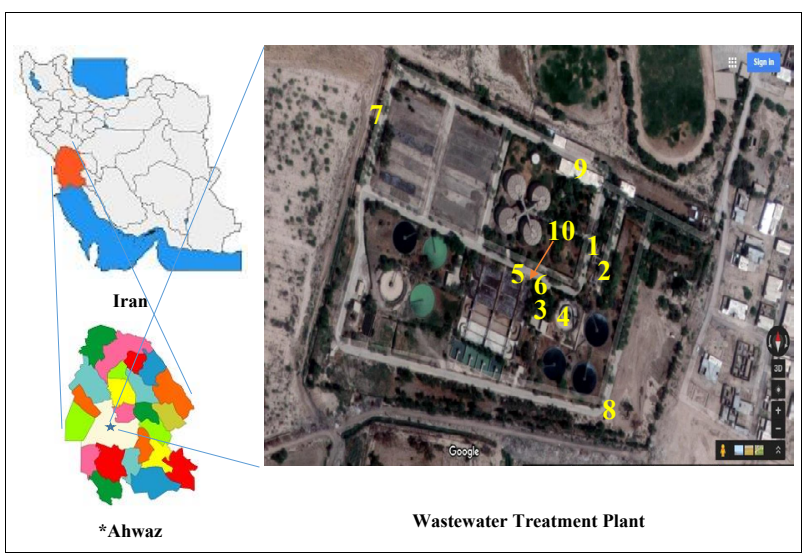

Figure 1. Geographical location and sampling points of the WWTP in the west of Ahvaz; (1) $2 \mathrm{~m}$ away from the $\mathrm{GCH}$; (2) $10 \mathrm{~m}$ away from the $\mathrm{GCH}$; (3) $2 \mathrm{~m}$ away from the PSDB; (4) $10 \mathrm{~m}$ away from the PSDB; (5) $2 \mathrm{~m}$ away from the AT; (6) $10 \mathrm{~m}$ away from the AT; (7) $60 \mathrm{~m}$ away from the US of dominant wind blowing at the site; (8) $60 \mathrm{~m}$ away from the DS of dominant wind blowing at the site; (9) AB; and (10) 6 m meters away from the AT.

\section{Materials and Methods \\ Study area}

This study was conducted on the main WWTP in Ahvaz, during both cold (January and February) and warm (June and July) seasons in 2018. Ahvaz is a region with an arid and warm climate $\left(4-48^{\circ} \mathrm{C}\right)$. The geographic location of the WWTP $\left(31^{\circ} 16^{\prime} \mathrm{N}, 48^{\circ} 36 \mathrm{E}^{\prime}\right)$ and sampling points are illustrated in Figure 1. The average operational flow to the plant was $600 \mathrm{~L} / \mathrm{s}$, and the treatment system was a conventional activated sludge. Details of the WWTP are described in Table 1.

\section{Sampling procedure}

Sampling was performed every 12 days in $10 \mathrm{~cm}$ plates according to the Environmental Protection Agency (EPA) schedule in 2018 (22). Sampling was also accomplished using passive sampling method and according to the microbiological sampling index of the air, which is known as the $1 / 1 / 1$ standard (at 1-meter height and a 1-meter distance from the walls and sources for 1 hour) $(23,24)$. Passive sampling feasibly is the most available, economic, and unobtrusive method of bioaerosol sampling and relies

Table 1. Details of the wastewater treatment plant

\begin{tabular}{|c|c|c|c|c|}
\hline Units & Number & & Dimension & \\
\hline Screening & 3 & & Width $1.5 \mathrm{~m}$ & \\
\hline Grit chamber & 2 & Diameter 3 m & - & Volume $25.4 \mathrm{~m}^{3}$ \\
\hline Primary sedimentation tanks & 4 & Diameter $3 \mathrm{~m}$ & Depth $2.45 \mathrm{~m}$ & - \\
\hline Aeration tank & 4 & & Volume $2914 \mathrm{~m}^{3}$ & \\
\hline Secondary sedimentation tanks & 4 & Diameter $2 \mathrm{~m}$ & Depth $2.1 \mathrm{~m}$ & Volume1385 m³ \\
\hline Chlorine contact basin & 2 & & Volume $480 \mathrm{~m}^{3}$ & \\
\hline Sludge digestion tanks & 4 & Diameter 20 m & Depth $10.5 \mathrm{~m}$ & Volume $4350 \mathrm{~m}^{3}$ \\
\hline Drying sludge bed & 8 & & Volume $9120 \mathrm{~m}^{3}$ & \\
\hline Gas tank & 1 & Diameter 9.15 m & Depth $4.8 \mathrm{~m}$ & Volume $250 \mathrm{~m}^{3}$ \\
\hline
\end{tabular}


Table 2. Location/sampling points

\begin{tabular}{ll}
\hline Location/Sampling Points & Description \\
\hline 1 & $2 \mathrm{~m}$ away from the grit chamber tank \\
2 & $10 \mathrm{~m}$ away from the grit chamber tank \\
3 & $2 \mathrm{~m}$ away from the primary sludge dewatering basin \\
4 & $10 \mathrm{~m}$ away from the primary sludge dewatering basin \\
5 & $2 \mathrm{~m}$ away from the aeration tank \\
6 & $10 \mathrm{~m}$ away from the aeration tank \\
7 & $60 \mathrm{~m}$ away from the upstream of dominant wind blowing at the site \\
8 & $60 \mathrm{~m}$ away from the downstream of dominant wind blowing at the site \\
9 & Administrative building \\
10 & $6 \mathrm{~m}$ away from the aeration tank \\
\hline
\end{tabular}

Table 3. Number of the fungi samples during the study

\begin{tabular}{|c|c|c|c|c|c|c|c|c|c|c|c|c|c|c|c|c|c|c|c|c|}
\hline \multirow{2}{*}{$\begin{array}{l}\text { Season } \\
\text { Sampling points }\end{array}$} & \multicolumn{10}{|c|}{ Cold } & \multicolumn{10}{|c|}{ Warm } \\
\hline & 1 & 2 & 3 & 4 & 5 & 6 & 7 & 8 & 9 & 10 & 1 & 2 & 3 & 4 & 5 & 6 & 7 & 8 & 9 & 10 \\
\hline Number of fungi samples & 10 & 10 & 10 & 10 & 10 & 10 & 10 & 10 & 10 & 12 & 10 & 10 & 10 & 10 & 10 & 10 & 10 & 10 & 10 & 12 \\
\hline Total number of fungi samples & 102 & & & & & & & & & & 102 & & & & & & & & & \\
\hline
\end{tabular}

on particles settling employing gravity, on a collection substrate holed in a settling plate (25). As shown in Table 2 , the sampling was performed at the same time from 9 points, considering the location of the unit of the WWTP in the west of Ahvaz. As presented in Table 3, a total of 204 samples were taken. Samples were taken to examine the hourly changes of the fungal concentration in the air around the aeration unit at a distance of $6 \mathrm{~m}$ from the aeration unit, in both cold and warm seasons, during 12 hours and every 2 hours. Sampling was randomized from $8 \mathrm{AM}$ to $6 \mathrm{PM}$. In this study, meteorological parameters including temperature, relative humidity, wind speed, and ultraviolet index (UV) were measured using AccuWeather software (26).

\section{Identification of airborne fungi}

The specific culture medium for fungi was Sabouraud's dextrose agar, which was used as chloramphenicol antibiotic $(100 \mathrm{mg} / \mathrm{L})$ to inhibit bacterial growth in the fungal culture medium (27-30). After each sampling stage, the samples were transferred to the laboratory in zipped bags with a cold box within less than 4 hours (24). The fungal culture medium was placed in an incubator at 25 to $30^{\circ} \mathrm{C}$ for $72-96$ hours whereby colony counting was performed $(31,32)$. The results of measuring the microbial parameters were reported as CFU/plate/h (the colony formation unit per plate per hour). Using typical laboratory methods (slide culture) and macroscopic and microscopic characteristics (under a light microscope with $100 \times 400$ magnification), the fungal genus was determined $(14,33,34)$.

\section{Statistical analysis}

The findings were analyzed using Excel software and SPSS 22. Kolmogorov-Smirnov test was performed to determine the normality of the data (14). Also, the Kruskal-Wallis test was employed to compare the mean concentration of fungi among the units during the study (35). Spearman correlation coefficient was used to find the correlation between fungal and meteorological parameters. Statistical significant values were considered at $P<0.05$ (36).

\section{Results}

Fungal aerosols concentrations at different sampling points

Figure 2 shows the mean concentration of fungal aerosols (CFU/plate/h) in different sampling points during both cold and warm seasons. As shown in this figure, the

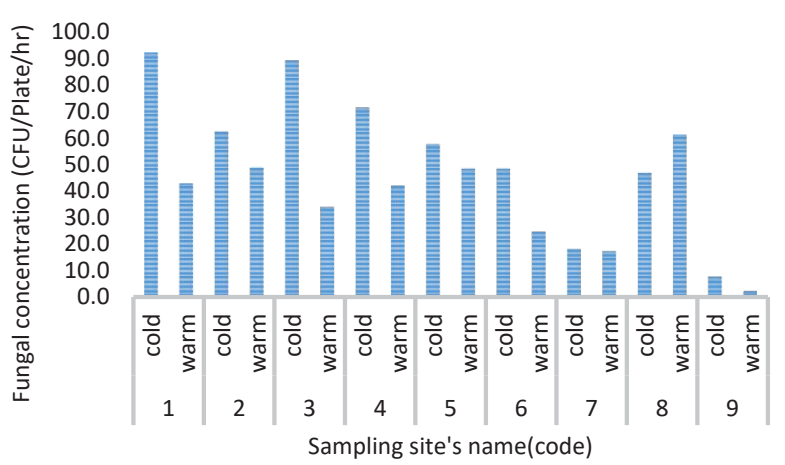

Figure 2. Mean concentration of fungal aerosols (CFU/plate/h) in different sampling points in different seasons 


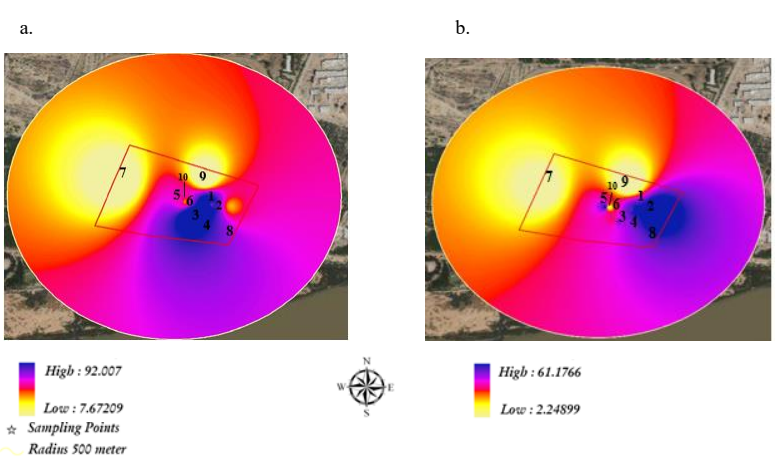

Figure 3. Spatial distributions of fungal aerosols concentration across the wastewater treatment plant in different sampling points during both (a) cold and (b) warm seasons (Redline delineates the border of wastewater treatment plant)

highest and lowest concentrations of fungi are related to the distance of $2 \mathrm{~m}$ from grit chamber with an average concentration of $92.2 \pm 28.12 \mathrm{CFU} /$ plate/h and a distance of $10 \mathrm{~m}$ from the AT with an average concentration of $24.6 \pm 6.67 \mathrm{CFU} /$ plate/h, respectively. Also, the mean concentration of fungal aerosols (CFU/plate/h) was higher during cold seasons than warm seasons $(P<0.05)$. The spatial distributions of fungal aerosols concentration across the WWTP during both cold and warm seasons are illustrated in Figure 3. The results revealed a significant difference between the fungal concentration (CFU/ plate/h) in the office building and ambient air in the WWTP $(P<0.05)$. According to the results, the fungal concentration in the office indoor air was less than that in the ambient air. The results indicated that there was a statistically significant difference between the degree of fungal contamination in different units, and upstream and downstream of the WWTP $(P<0.05)$. Furthermore, the findings indicated that the highest amounts of fungal aerosols were released in the early morning.

The relationship between meteorological parameters and fungal aerosol concentrations

During the study, temperature, relative humidity, wind speed, and UV index were within the range of 7.14 to $41^{\circ} \mathrm{C}, 10.78$ to $55.47 \%, 3.82$ to $15.18 \mathrm{~km} / \mathrm{h}$, and 1.7 to 6 , respectively. The average amounts of these parameters are presented in Table 4. The highest and lowest amounts of fungal aerosols were released in the cold and warm seasons, respectively. In both seasons, Cladosporium was known as the dominant genus. Cladosporium has a high heat growth domain and can grow even at $-8^{\circ} \mathrm{C}(20)$. As shown in Table 5 , there was no significant correlation between the release of fungi and temperature, humidity, or wind speed. However, there was a significant negative correlation between the total fungal concentration and UV index $(P<0.05)$.

Isolated fungi genus

In this study, at least 17 species of fungi were isolated. Cladosporium (39.23\%) was the most common fungal genus in the ambient sampling points. It was followed by Alternaria (19.87\%), Yeast (12.45\%), and Aspergillus (11.79\%). The dominant genus in the administrative building was also Cladosporium, which was $14.77 \%$ more than the fungus inside the building. The percentages of airborne fungal genera during the study are presented in Figure 4.

\section{Discussion}

Urban wastewater entering the WWTP involves large amounts of pathogens, such as viruses, bacteria, and fungi,

Table 4. Descriptive statistics of meteorological parameters during the study

\begin{tabular}{|c|c|c|c|c|c|c|c|c|}
\hline \multirow{3}{*}{$\begin{array}{l}\text { Meteorological Parameters } \\
\text { Range } \\
\text { Season }\end{array}$} & \multicolumn{2}{|c|}{ Temperature $\left({ }^{\circ} \mathrm{C}\right)$} & \multicolumn{2}{|c|}{ Wind Speed (km/h) } & \multicolumn{2}{|c|}{ Ultraviolet Index } & \multicolumn{2}{|c|}{ Humidity (\%) } \\
\hline & \multicolumn{2}{|c|}{$(14.7-41)$} & \multicolumn{2}{|c|}{$(3.8-15.2)$} & \multicolumn{2}{|c|}{$(1.7-6)$} & \multicolumn{2}{|c|}{$(10.8-55.5)$} \\
\hline & Winter & Summer & Winter & Summer & Winter & Summer & Winter & Summer \\
\hline Maximum & 23.0 & 46.0 & 4.0 & 26.0 & 3.0 & 12.0 & 81.0 & 18.0 \\
\hline Minimum & 7.0 & 33.0 & 3.0 & 6.0 & 1.0 & 2.0 & 17.0 & 5.0 \\
\hline Mean & 14.7 & 41.0 & 3.8 & 15.2 & 1.7 & 6.0 & 55.5 & 10.8 \\
\hline SD & 0.9 & 0.7 & 0.1 & 1.1 & 0.1 & 0.6 & 3.2 & 0.6 \\
\hline
\end{tabular}

Table 5. Correlation between the meteorological parameters and the total fungal concentration (CFU/plate/h) during the study

\begin{tabular}{|c|c|c|c|c|c|}
\hline & Temperature $\left({ }^{\circ} \mathrm{C}\right)$ & Wind Speed $(\mathrm{km} / \mathrm{h})$ & Ultraviolet Index & Humidity (\%) & Total Fungal \\
\hline Temperature $\left({ }^{\circ} \mathrm{C}\right)$ & 1 & & & & \\
\hline Wind speed $(\mathrm{km} / \mathrm{h})$ & $0.856^{* *}$ & 1 & & & \\
\hline Ultraviolet Index & $0.747^{* *}$ & $0.462^{* *}$ & 1 & & \\
\hline Humidity (\%) & $-0.968^{* *}$ & $-0.842^{* *}$ & $-0.745 * *$ & 1 & \\
\hline Total fungal & -0.113 & -0.159 & $-0.236 *$ & 0.082 & 1 \\
\hline
\end{tabular}

Significant: $* * P<0.01$ and $* P<0.05$ 


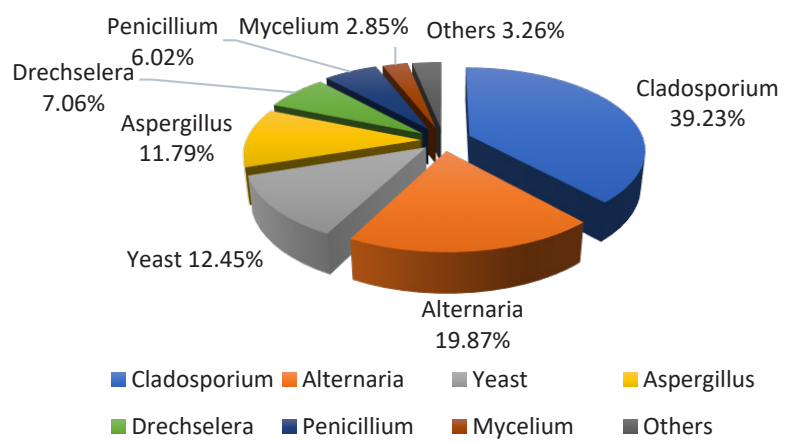

Figure 4. Percentages of airborne fungal genera during the study.

which can easily enter the air through several units and processes $(16,37,38)$. To the best of our knowledge, there are no obvious existing in other countries, however, some countries have published occupational limit values and suggested them as a point of starting an assessment (39). Several studies have suggested that the structure, size, concentration, and microbial population of bioaerosols is affected by the source of production, the mechanism of air diffusion, and in general, the weather conditions, such as temperature, humidity, wind speed, and UV index (1214). Shams-Ghahfarokhi et al found 24 different fungal genera, where the most frequently isolated fungi included Aspergillus (31.1\%), Cladosporium (22.1\%), Penicillium (13.8\%), and Alternaria (22.2\%), respectively (40). Also, Ding et al reported Penicillium spp. and Aspergillus spp. as the most frequent fungi in the WWTP with an oxidation ditch system in summer (41). In this study, the results demonstrated that among the selected units, the highest concentrations of fungi were observed in the grit chamber unit. This can be due to the aeration system, bubble formation, and grit chamber geographic location, which is located at the downstream of the dominant wind direction in Ahvaz. Breza-Boruta and Paluszak studied the role of water treatment units in the microbiological composition of bioaerosols and found that the grit chamber unit is the most important source of bioaerosols (42). Li et al examined the release of bioaerosols from the WWTP using the
Orbal oxidation ditch process. They found that the highest levels of fungal contamination caused by the grit chamber unit (43). Kermani et al found that microorganisms scatter in the air mainly through mechanical treatment such as moving sewage or during biological treatment such as aeration (20). In the present study, there was no significant correlation between the release of fungi and temperature, humidity, and wind speed. However, there was a significant negative correlation between the release of fungi and UV index. The largest amount of fungal aerosols was released in the early morning due to the low UV index. Katsivela et al found no significant relationship between the fungi and temperature. This suggests that the lack of relationship between temperature and fungi may be due to the temperature changes affected by another meteorological parameter (44). Furthermore, the air microbial and chemical composition of each region and particle concentration are important. Several studies have suggested that the changes in microbial concentration are affected by various meteorological parameters, chemical and microbial composition of each region, and particle concentration (45-47). Some studies have indicated that microbial particles in different sizes were not equally affected by climatic conditions. This can be attributed to the existence of microbial particles in different sizes, different species, as well as in different phases of growth $(44,48,49)$. In some studies, fungal particles with 0.65 $1.1 \mu \mathrm{m}$ diameters had a positive correlation with wind speed and negative correlation with the UV index $(50,51)$. Almeida et al found that temperature and wind speed had a positive correlation with the release of Alternaria spp. and Cladosporium spp. and negative correlation with humidity (52). In this study, the greatest release of fungal aerosols occurred in the cold season while the minimum release occurred in the warm season, which is consistent with the results of studies by Pasquarella et al (2) and Niazi et al (14). In contrast, Fathi et al observed a high concentration of airborne fungi in summer (16). Also, Xie et al reported that the concentrations of airborne contamination were high in winter, fall, spring, and summer, respectively.

Table 6. Performance comparison between some studies and this study

\begin{tabular}{|c|c|c|c|c|c|c|c|}
\hline $\begin{array}{l}\text { Effective Meteorological } \\
\text { Parameter }\end{array}$ & $\begin{array}{l}\text { Treatment } \\
\text { System }\end{array}$ & Effective Unit & Season & $\begin{array}{l}\text { Temperature } \\
\text { ( } \mathrm{C} \text { ) }\end{array}$ & Humidity & $\begin{array}{l}\text { Dominant Fungi } \\
\text { Genera }\end{array}$ & Reference \\
\hline Relative humidity & $\begin{array}{l}\text { Activated } \\
\text { sludge }\end{array}$ & $\begin{array}{l}\text { Primary } \\
\text { sedimentation unit }\end{array}$ & Summer & $7-30$ & $29.4-50.4$ & $\begin{array}{l}\text { Penicillium spp. and } \\
\text { Cladosporium spp. }\end{array}$ & 14 \\
\hline $\begin{array}{l}\text { Temperature, humidity, } \\
\text { wind speed, and UV }\end{array}$ & $\begin{array}{l}\text { Activated } \\
\text { sludge }\end{array}$ & Grit chamber & Winter & $3-34$ & $11-49$ & $\begin{array}{l}\text { Cladosporium spp. } \\
\text { and Alternaria spp. }\end{array}$ & 19 \\
\hline Nothing & $\begin{array}{l}\text { Activated } \\
\text { sludge }\end{array}$ & Aeration tank & Summer & $9-23.6$ & $27-55.5$ & Dematiaceous & 16 \\
\hline $\begin{array}{l}\text { High temperature and } \\
\text { relative humidity }\end{array}$ & $\begin{array}{l}\text { Oxidation } \\
\text { ditch }\end{array}$ & - & Summer & $11-27.4$ & $17-80$ & $\begin{array}{l}\text { Penicillium spp. and } \\
\text { Aspergillus spp. }\end{array}$ & 41 \\
\hline UV & $\begin{array}{l}\text { Activated } \\
\text { sludge }\end{array}$ & Grit chamber & Winter & $14.7-41$ & $10.8-55.5$ & $\begin{array}{l}\text { Cladosporium spp. } \\
\text { and Alternaria spp. }\end{array}$ & This study \\
\hline
\end{tabular}


They also found that snowfall reduces the level of airborne microbial contamination (53). Comparative analysis of the results of this study and some studies is illustrated in Table 6. High relative humidity along with low temperature leads to the formation of bioaerosols in winter (54). Due to the ability of fungi to being adapted with many environmental conditions, fungi easily endanger people's life with disabilities and immune deficiencies and nowadays are considered as one of the most important causes of death (10). Exposure to high concentrations of airborne fungal spores is associated with allergic rhinitis and asthma. Besides, the total number of fungal spores, Basidiospores, and Cladosporium was a risk factor in these findings. Fungal spores, such as Cladosporium, Aspergillosis, Penicillium, Alternaria, Fusarium, and Basidiospores are critical factors in the development of allergic diseases. Allergic rhinitis and asthma are more frequent in fall and winter. The exposure of wastewater treatment workers to bioaerosols causes an extensive range of health effects such as infectious diseases, chronic obstructive pulmonary disease, acute toxic effects, inflammation, allergic diseases, fetal harm, and cancer (19). Carducci et al analyzed the quantitative microbial risk assessment for workers exposed to bioaerosols in WWTPs. They found that these effects were extended along with increasing the concentration of contamination and exposure time (55).

\section{Conclusion}

This study examined the concentration of airborne fungi around grit chamber, PSDB, and AT, as well as administrative buildings (where people spend $80 \%$ of their time), upstream and downstream of the wind direction of the WWTP in the West of Ahvaz and its relationship with meteorological parameters. According to the results, the WWTP released significant amounts of fungal spores. As the residential houses are located downstream of the WWTP and dominant winds of Ahvaz, therefore, WWTP workers and the people who live near the WWTP were exposed to high concentrations of aerosols, which threaten their health condition. It seems that the assessment of occupational risk factors in the WWTP, the development of occupational safety and health practices, especially on risk assessment, health monitoring, fitness, immunization, and preventive measures in water supply facilities, benchmarking, and participation in investigating the biological risk factors can be effective in reducing the harmful effects of bioaerosols. Also, using double-glazed windows and doors, as well as using air conditioners, can be considered as other ways for preventing the harmful effects of bioaerosols in the indoor environment.

\section{Acknowledgments}

The authors would like to thank the Environmental Technologies Research Center of Ahvaz Jundishapur University of Medical sciences, Ahvaz, Iran for its financial support (Ethic number: IR.AJUMS.REC.1397.188).

\section{Ethical issues}

The authors certify that this manuscript is the original work of the authors, all data collected during the study are presented in the manuscript, and no data from the study has been or will be published separately.

\section{Competing interests}

The authors declare that they have no conflict of interests.

\section{Authors' contributions}

All authors contributed and participated equally in the data collection, analysis, and interpretation. All authors critically reviewed, refined, and approved the manuscript.

\section{References}

1. Douwes J, Thorne P, Pearce N, Heederik D. Bioaerosol health effects and exposure assessment: progress and prospects. Ann Occup Hyg 2003; 47(3): 187-200. doi: 10.1093/annhyg/meg032.

2. Pasquarella C, Pitzurra O, Savino A. The index of microbial air contamination. J Hosp Infect 2000; 46(4): 241-56. doi: 10.1053/jhin.2000.0820.

3. Simkhovich BZ, Kleinman MT, Kloner RA. Particulate air pollution and coronary heart disease. Curr Opin Cardiol 2009; 24(6): 604-9. doi: 10.1097/HCO.0b013e32833161e5.

4. Guo Y, Jia Y, Pan X, Liu L, Wichmann HE. The association between fine particulate air pollution and hospital emergency room visits for cardiovascular diseases in Beijing, China. Sci Total Environ 2009; 407(17): 4826-30. doi: $\quad 10.1016 /$ j.scitotenv.2009.05.022.

5. Sabino R, Veríssimo C, Viegas C, Viegas S, Brandão J, Alves-Correia M, et al. The role of occupational Aspergillus exposure in the development of diseases. Med Mycol 2019; 57(Suppl_2): S196-S205. doi: 10.1093/mmy/myy090.

6. Garaga R, Avinash CK, Kota SH. Seasonal variation of airborne allergenic fungal spores in ambient PM10-a study in Guwahati, the largest city of north-east India. Air Quality Atmosphere \& Health 2019; 12(1): 11-20. doi: 10.1007/s11869-018-0624-y.

7. Griffiths WD, Bennett A, Speight S, Parks S. Determining the performance of a commercial air purification system for reducing airborne contamination using model microorganisms: a new test methodology. J Hosp Infect 2005; 61(3): 242-7. doi: 10.1016/j.jhin.2005.03.004.

8. Degobbi C, Lopes FD, Carvalho-Oliveira R, Muñoz JE, Saldiva PH. Correlation of fungi and endotoxin with PM2.5 and meteorological parameters in atmosphere of Sao Paulo, Brazil. Atmos Environ 2011; 45(13): 2277-83. doi: 10.1016/j. atmosenv.2010.12.005.

9. Macher J. Bioaerosols: Assessment and Control. Cincinnati, Ohio: American Conference of Governmental Industrial Hygienists; 1999.

10. Dehdashti A, Sahranavard N, Rostami R, Barkhordari A, Banayi Z. Survey of bioaerosols type and concentration in the ambient air of hospitals in Damghan, Iran. Tibbi- i- Kar Journal 2012; 4(3): 41-51. [In Persian].

11. Bredholt H, Fjaervik E, Johnsen G, Zotchev SB. Actinomycetes from sediments in the Trondheim fjord, Norway: diversity and biological activity. Mar Drugs 2008; 
6(1): $12-24$.

12. Fannin KF, Vana SC, Jakubowski W. Effect of an activated sludge wastewater treatment plant on ambient air densities of aerosols containing bacteria and viruses. Appl Environ Microbiol 1985; 49(5): 1191-6. doi: 10.1128/aem.49.5.11911196.1985

13. Sánchez-Monedero MA, Aguilar MI, Fenoll R, Roig A. Effect of the aeration system on the levels of airborne microorganisms generated at wastewater treatment plants. Water Res 2008; 42(14): 3739-44. doi: 10.1016/j. watres.2008.06.028.

14. Niazi S, Hassanvand MS, Mahvi AH, Nabizadeh R, Alimohammadi M, Nabavi S, et al. Assessment of bioaerosol contamination (bacteria and fungi) in the largest urban wastewater treatment plant in the Middle East. Environ Sci Pollut Res Int 2015; 22(20): 16014-21. doi: 10.1007/s11356015-4793-Z.

15. Basart $\mathrm{S}$, Pay MT, Jorba O, Pérez García-Pando C, Jiménez Guerrero P, Schulz M, et al. Aerosols in the CALIOPE air quality modelling system: evaluation and analysis of PM levels, optical depths and chemical composition over Europe. Atmos Chem Phys 2012; 12(7): 3363-92. doi: 10.5194/acp-12-3363-2012.

16. Fathi S, Hajizadeh Y, Nikaeen M, Gorbani M. Assessment of microbial aerosol emissions in an urban wastewater treatment plant operated with activated sludge process. Aerobiologia 2017; 33(4): 507-15. doi: 10.1007/s10453-0179486-2.

17. Sadeghi Hasanvand Z, Sekhavatjo MS, Zakavat R. Assessment the bio-aerosols type and concentration in various wards of Valiasr hospital, Khorramshahr during 2011. Iran J Health Environ 2013; 6(2): 201-10. [In Persian].

18. Kermani M, Bahrami Asl F, Farzadkia M, Naddafi K, Zeynalzadeh D, Dehghani A. Concentration and distribution of airborne fungi in the ambient air of Milad hospital, blood transfusion organization, and Shahrake Ghods wastewater treatment plant in Tehran, Iran. Journal of Health Research in Community 2015; 1(3): 1-8. [In Persian].

19. Kallawicha K, Chuang YC, Lung SC, Wu CF, Han BC, Ting YF, et al. Outpatient visits for allergic diseases are associated with exposure to ambient fungal spores in the greater Taipei area. Aerosol Air Qual Res 2018; 18(8): 2077-85. doi: 10.4209/aaqr.2018.01.0028.

20. Kermani M, Dehghani A, Farzadkia M, Nadafi K, Bahrami Asl F, Zeinalzadeh D. Investigation of airborne bactria and fungi in Tehran's Shahrake Ghods WWTP and its association with environmental parameters. J Health 2015; 6(1): 57-68. [In Persian].

21. Burkowska-But A, Kalwasińska A, Walczak M. Airborne mesophilic bacteria at the Ciechocinek health resort. Pol J Environ Stud 2012; 21(2): 307-12.

22. Ambient Monitoring Technology Information Center (AMTIC). Sampling Schedule Calendar. [cited 2018 Oct 17] Available from: https://www3.epa.gov/ttnamti1/files/ ambient/pm25/calendar.html

23. Napoli C. Prevention of healthcare-associated infections: which sampling method should be used to evaluate air biocontamination in operating rooms? Epidemiol 2012; 2(2): e106. doi: 10.4172/2161-1165.1000e106.

24. Abdel Hameed AA, Khoder MI, Yuosra S, Osman AM,
Ghanem S. Diurnal distribution of airborne bacteria and fungi in the atmosphere of Helwan area, Egypt. Sci Total Environ 2009; 407(24): 6217-22. doi: 10.1016/j. scitotenv.2009.08.028.

25. Haig CW, Mackay WG, Walker JT, Williams C. Bioaerosol sampling: sampling mechanisms, bioefficiency and field studies. J Hosp Infect 2016; 93(3): 242-55. doi: 10.1016/j. jhin.2016.03.017.

26. AccWeather. Iran Satellite. [cited 2019 Oct 17] Available from: https://www.accuweather.com/.

27. Kim KY, Kim HT, Kim D, Nakajima J, Higuchi T. Distribution characteristics of airborne bacteria and fungi in the feedstuff-manufacturing factories. J Hazard Mater 2009; 169(1-3): 1054-60. doi: 10.1016/j.jhazmat.2009.04.059.

28. Lee JH, Jo WK. Characteristics of indoor and outdoor bioaerosols at Korean high-rise apartment buildings. Environ Res 2006; 101(1): 11-7. doi: 10.1016/j. envres.2005.08.009.

29. Wang W, Ma Y, Ma X, Wu F, Ma X, An L, et al. Seasonal variations of airborne bacteria in the Mogao Grottoes, Dunhuang, China. Int Biodeterior Biodegradation 2010; 64(4): 309-15. doi: 10.1016/j.ibiod.2010.03.004.

30. Nourmoradi H, Amin MM, Hatamzadeh $M$, Nikaeen M. Evaluation of bio-aerosols concentration in the different wards of three educational hospitals in Iran. Int J Environ Health Eng 2012; 1(6): 12-5. doi: 10.4103/22779183.105346.

31. Scaltriti S, Cencetti S, Rovesti S, Marchesi I, Bargellini A, Borella P. Risk factors for particulate and microbial contamination of air in operating theatres. J Hosp Infect 2007; 66(4): 320-6. doi: 10.1016/j.jhin.2007.05.019.

32. Kibbler CC, Barton R, Gow NA, Howell S, MacCallum DM, Manuel RJ. Oxford Textbook of Medical Mycology. Oxford: Oxford University Press; 2017. doi: 10.1093/ med/9780198755388.001.0001.

33. Asefa DT, Langsrud S, Gjerde RO, Kure CF, Sidhu MS, Nesbakken T, et al. The performance of SAS-super-180 air sampler and settle plates for assessing viable fungal particles in the air of dry-cured meat production facility. Food Control 2009; 20(11): 997-1001. doi: 10.1016/j. foodcont.2008.11.011.

34. Gniadek A, Macura AB, Oksiejczuk E, Krajewska-Kułak E, Łukaszuk C. Fungi in the air of selected social welfare homes in the Małopolskie and Podlaskie provinces-a comparative study. Int Biodeterior Biodegradation 2005; 55(2): 85-91. doi: 10.1016/j.ibiod.2004.07.005.

35. Michałkiewicz M. Comparison of wastewater treatment plants based on the emissions of microbiological contaminants. Environ Monit Assess 2018; 190(11): 640. doi: $\quad$ 10.1007/s10661-018-7035-2.

36. Kumar P, Goel A. Temporal variations in fungal bioaerosols in outdoor environment: a three year study at four different locations in Gwalior, Central India. Def Life Sci J 2019; 4(1): 76-81. doi: 10.14429/dlsj.4.12537.

37. Carducci A, Tozzi E, Rubulotta E, Casini B, Cantiani L, Rovini E, et al. Assessing airborne biological hazard from urban wastewater treatment. Water Res 2000; 34(4): 1173-8. doi: 10.1016/s0043-1354(99)00264-x.

38. Viegas C, Dias R, Gomes AQ, Meneses M, Sabino R, Viegas S. Aspergillus flavus contamination in two Portuguese wastewater treatment plants. J Toxicol 
Environ Health A 2014; 77(14-16): 796-805. doi: $10.1080 / 15287394.2014 .909300$.

39. Pearson C, Littlewood E, Douglas P, Robertson S, Gant TW, Hansell AL. Exposures and health outcomes in relation to bioaerosol emissions from composting facilities: a systematic review of occupational and community studies. J Toxicol Environ Health B Crit Rev 2015; 18(1): 43-69. doi: 10.1080/10937404.2015.1009961.

40. Shams-Ghahfarokhi M, Aghaei-Gharehbolagh S, Aslani $\mathrm{N}$, Razzaghi-Abyaneh M. Investigation on distribution of airborne fungi in outdoor environment in Tehran, Iran. J Environ Health Sci Eng 2014; 12(1): 54. doi: 10.1186/2052$336 x-12-54$

41. Ding W, Li L, Han Y, Liu J, Liu J. Site-related and seasonal variation of bioaerosol emission in an indoor wastewater treatment station: level, characteristics of particle size, and microbial structure. Aerobiologia 2016; 32(2): 211-24. doi: 10.1007/s10453-015-9391-5.

42. Breza-Boruta B, Paluszak Z. Influence of water treatment plant on microbiological composition of air bioaerosol. Pol J Environ Stud 2007; 16(5): 663-70.

43. Li L, Gao M, Liu J. Distribution characterization of microbial aerosols emitted from a wastewater treatment plant using the Orbal oxidation ditch process. Process Biochem 2011; 46(4): 910-5. doi: 10.1016/j.procbio.2010.12.016.

44. Katsivela E, Latos E, Raisi L, Aleksandropoulou V, Lazaridis M. Particle size distribution of cultivable airborne microbes and inhalable particulate matter in a wastewater treatment plant facility. Aerobiologia 2017; 33(3): 297-314. doi: 10.1007/s10453-016-9470-2.

45. Brodie EL, DeSantis TZ, Parker JP, Zubietta IX, Piceno YM, Andersen GL. Urban aerosols harbor diverse and dynamic bacterial populations. Proc Natl Acad Sci U S A 2007; 104(1): 299-304. doi: 10.1073/pnas.0608255104.

46. Bertolini V, Gandolfi I, Ambrosini R, Bestetti G, Innocente E, Rampazzo G, et al. Temporal variability and effect of environmental variables on airborne bacterial communities in an urban area of Northern Italy. Appl Microbiol Biotechnol 2013; 97(14): 6561-70. doi: 10.1007/s00253-
012-4450-0.

47. Seifried JS, Wichels A, Gerdts G. Spatial distribution of marine airborne bacterial communities. Microbiologyopen 2015; 4(3): 475-90. doi: 10.1002/mbo3.253.

48. Oliveira M, Ribeiro H, Delgado JL, Abreu I. The effects of meteorological factors on airborne fungal spore concentration in two areas differing in urbanisation level. Int J Biometeorol 2009; 53(1): 61-73. doi: 10.1007/s00484008-0191-2.

49. Pyrri I, Kapsanaki-Gotsi E. Diversity and annual fluctuations of culturable airborne fungi in Athens, Greece: a 4-year study. Aerobiologia 2012; 28(2): 249-62. doi: 10.1007/s10453-011-9233-z.

50. Karra S, Katsivela E. Microorganisms in bioaerosol emissions from wastewater treatment plants during summer at a Mediterranean site. Water Res 2007; 41(6): 1355-65. doi: 10.1016/j.watres.2006.12.014.

51. Hung HF, Kuo YM, Chien CC, Chen CC. Use of floating balls for reducing bacterial aerosol emissions from aeration in wastewater treatment processes. J Hazard Mater 2010; 175(1-3): 866-71. doi: 10.1016/j.jhazmat.2009.10.090.

52. Almeida E, Caeiro E, Todo-Bom A, Ferro R, Dionísio A, Duarte A, et al. The influence of meteorological parameters on Alternaria and Cladosporium fungal spore concentrations in Beja (Southern Portugal): preliminary results. Aerobiologia 2018; 34(2): 219-26. doi: 10.1007/ s10453-018-9508-8.

53. Xie Z, Li Y, Lu R, Li W, Fan C, Liu P, et al. Characteristics of total airborne microbes at various air quality levels. J Aerosol Sci 2018; 116: 57-65. doi: 10.1016/j.jaerosci.2017.11.001.

54. Qi J, Shao Q, Xu W, Gao D, Jin C. Seasonal distribution of bioaerosols in the coastal region of Qingdao. J Ocean Univ China 2014; 13(1): 57-65. doi: 10.1007/s11802-014-1951-8.

55. Carducci A, Donzelli G, Cioni L, Federigi I, Lombardi R, Verani M. Quantitative microbial risk assessment for workers exposed to bioaerosol in wastewater treatment plants aimed at the choice and setup of safety measures. Int J Environ Res Public Health 2018; 15(7): 1490. doi: 10.3390/ ijerph15071490. 